\title{
Supply of the dairy cow with amino acids from dietary protein
}

\author{
T. Hvelplund, L. Misciattelli and M. R. Weisbjerg \\ Danish Institute of Agricultural Sciences, \\ Department of Animal Nutrition and Physiology, \\ Research Centre Foulum \\ 8830 Tjele, Denmark
}

\section{ABSTRACT}

Microbial protein produced in the rumen is not sufficient to meet the requirement for amino acids of the high producing dairy cow. The microbial protein thus need to be supplemented with a certain amount of undegraded protein which match the microbial protein both quantitatively and qualitatively to enable an efficient utilization for milk production. This paper summarizes findings with respect to amino acid composition and digestibility of microbial amino acids. The main emphasis is however on recent findings with respect to degradability and digestibility of individual amino acids in feed proteins. The results seem to indicate that degradability and digestibility estimates obtained for nitrogen may not always apply to individual amino acids. It is concluded that more research is needed to identify the ideal profile of the amino acids absorbed from the intestine of lactating cows. Results of such efforts are needed to compose an ideal protein supplement eventually by using protected amino acids to balance the microbial protein to meet the amino acid requirement of dairy cattle with a minimum of rumen undegraded protein.

KEY WORDS: undegraded protein, microbial protein, degradability, intestinal digestibility

\section{INTRODUCTION}

The amino acids flowing to the small intestine of ruminants is a mixture of undegraded protein of dietary origin, microbial protein synthesised in the rumen, free peptides and amino acids escaping rumen degradation and endogenous protein secretions and abraded epithelial cells. To optimise the amino acid composition of the protein passing the duodenum, it is necessary to balance the amino acid composition of ruminally synthesised microbial protein, with rumen undegraded feed protein. The microbial protein produced in the rumen typically supplies the 
majority of the amino acids flowing to the small intestine of dairy cows (Hvelplund and Madsen, 1985; Clark et al., 1992) and the microbial flow is primarily of bacterial origin although both protozoa and fungi may contribute to some extent based on the actual feeding situation. To obtain an efficient microbial protein synthesis in the rumen the protein in the feed should meet the requirement for degradable protein in the rumen and at the same time supply the animal with undegraded protein which match the microbial protein both quantitatively and qualitatively for an efficient utilization for milk production.

The paper summarizes some recent findings with respect to amino acid supply of the dairy cow with special emphasis on degradability of amino acids in the feed protein and intestinal digestibility of amino acids in undegraded protein.

HOW MUCH MILK CAN BE PRODUCED FROM MICROBIAL PROTEIN AS THE ONLY PROTEIN SOURCE?

Microbial protein produced in the rumen is related to the amount of fermented organic matter in the rumen and in the Nordic protein evaluation system it is related to the amount of carbohydrates fermented in the rumen. Assuming that a constant proportion of the carbohydrates is digested in the hindgut, the value is calculated from totally digested carbohydrates. In the Nordic protein evaluation system the amount of microbial amino acids produced per $\mathrm{kg}$ of totally digested carbohydrates is $125 \mathrm{~g}$ amino acids. This amount is sufficient to meet the requirement for a dairy cow producing approx. $10 \mathrm{~kg}$ of milk when energy is adjusted to meet the requirement (Hvelplund and Weisbjerg, 1995). At higher production levels it is necessary to supply the cow with rumen undegradable protein to meet the requirement for intestinally absorbable protein. In situations where the microbial protein is sufficient to meet the requirement, the question concerning limiting amino acids is related to the composition of the microbial protein. At production levels where microbial protein is not sufficient to meet the protein requirement, the composition of the undegraded protein becomes important in two respects. Any imbalance in the composition of the microbial protein should be adjusted and at the same time the total requirement should be fulfilled.

A further complication with respect to optimal supplementation of the microbial protein is the highly variable microbial synthesis in the rumen or more correctly the flow of microbial protein to the intestine as this value is highly variable from one feeding situation to the other. The efficiency of microbial protein synthesis may vary from 12 to $54 \mathrm{~g}$ microbial $\mathrm{N} / \mathrm{kg}$ organic matter fermented in the rumen (NRC, 2001) and this huge variability may imply that the production level based on microbial protein alone may vary from one feeding situation to the other and thereby also the requirement for undegraded dietary protein. The 
British protein evaluation system includes the variability in microbial protein synthesis and use different efficiencies of microbial protein synthesis at maintenance level of intake and at different multiples of maintenance, respectively (AFRC, 1992).

\section{VARIABILITY IN THE COMPOSITION OF PROTEIN PASSING TO THE DUO- DENUM}

Protein entering the small intestine is a mixture of microbial protein, undegraded dietary protein and endogenous protein. The amino acid (AA) profile of this mixture is reflected by the profile of the three sources and their contribution to the total flow. It has sometimes been postulated that the amino acid profile of the duodenal flow is relatively constant based on the extensive degradation of feed protein and the high proportion of microbial protein in the duodenal content. The amino acid composition of the protein entering the duodenum of dairy cows fed a variety of different diets at feeding levels varying from 5.5 to $20.2 \mathrm{~kg}$ dry matter per day is shown in Table 1. From the table it is evident that the diet may influence the amino

TABLE 1 Amino acid composition (gAA/100 gAA determined, $n=16$, Cys and Trp excluded) of duodenal chyme without any corrections for endogenous contributions ${ }^{1}$

\begin{tabular}{lrrcc}
\hline & Mean & SD & Minimum & Maximum \\
\hline Ala & 6.4 & 0.3 & 5.6 & 7.0 \\
Arg & 5.0 & 0.5 & 4.3 & 6.5 \\
Asp & 10.8 & 0.3 & 9.8 & 11.3 \\
Glu & 13.1 & 1.0 & 11.6 & 15.1 \\
Gly & 10.7 & 1.3 & 8.1 & 13.3 \\
His & 2.6 & 0.3 & 2.0 & 3.2 \\
Ile & 5.2 & 0.2 & 4.5 & 5.7 \\
Leu & 7.8 & 0.4 & 6.9 & 9.0 \\
Lys & 6.6 & 0.5 & 5.5 & 7.5 \\
Met & 1.8 & 0.2 & 1.4 & 2.3 \\
Phe & 4.8 & 0.4 & 3.9 & 5.6 \\
Pro & 4.3 & 0.6 & 3.7 & 6.6 \\
Ser & 5.3 & 0.3 & 4.8 & 6.5 \\
Thr & 5.2 & 0.2 & 4.6 & 5.6 \\
Tyr & 4.2 & 0.9 & 0.9 & 5.3 \\
Val & 6.1 & 0.4 & 5.6 & 7.5 \\
\hline
\end{tabular}

1 meta-analysis on data only from authors laboratory, 51 different diets fed to dairy cows $(n=2$ to 5$)$, at daily dry matter intakes from 5.5 to $20.2 \mathrm{~kg}$ and daily duodenal dry matter and total amino acid flows from 4.4 to $15.6 \mathrm{~kg} / \mathrm{d}$ and 725 to $3156 \mathrm{~g} / \mathrm{d}$, respectively 
acid composition of the duodenal chyme as the coefficient of variation for the essential amino acids range from 5 to $12 \%$.

For the two amino acids lysine and methionine, which often are considered first limiting for milk production, the minimum and average values found would indicate that the flow of lysine, at a duodenal flow of $2000 \mathrm{~g}$ of amino acids, would differ between the lowest and the mean value by $22 \mathrm{~g}$ while the difference for methionine would be $8 \mathrm{~g}$. Applying a digestibility of 0.85 and an efficiency of utilization for milk production of 0.90 this amount would equal $7 \mathrm{~kg}$ milk for lysine and $8 \mathrm{~kg}$ for methionine when the calculations are based on milk containing $32 \mathrm{~g}$ protein per $\mathrm{kg}$ with an average amino acid composition as shown in Table 3.

The variability in the amino acid composition of the duodenal protein shown in Table 1 is an effect of both variability in the composition of the microbial protein as well as in the undegraded dietary protein and the variability in the amino acid composition of these fractions are considered in the following.

\section{AMINO ACID COMPOSITION AND DIGESTIBILITY OF BACTERIAL PROTEIN}

Amino acid composition of bacterial protein isolated from the rumen is in earlier experiments found to be relatively constant (Purser and Buechler, 1966; Bergen et al., 1968). More recent research on composition of bacterial protein isolated from the rumen originating from many different dietary treatments have revealed major differences in the bacterial amino acid composition as shown in Table 2. Results are presented from different sources and as shown in the table there seems to be good agreement between the mean values, whereas the standard deviations do indicate considerable differences between the different isolates, as also demonstrated by the Danish isolates where the minimum and maximum values also are shown. Some of the variation may be ascribed to different methods of isolation of the bacteria as well as differences in analytical procedures. This is however not the case for the Danish values where the isolation procedure and the analytical method has been the same for all samples and this do indicate differences in microbial amino acid composition.

Besides bacteria the microbial fraction entering the small intestine also contains protozoa and fungi but the contribution from these two fractions is normally limited. The variability in the bacterial amino acid composition is thus the most important and therefore it is of great interest to identify the factors responsible for this variability in an attempt to optimize the amino acid composition of the protein entering the small intestine.

When evaluating the ability of the bacterial fraction to supply the animal with amino acids it is also necessary to consider the intestinal digestibility of the individual amino acids. Estimates of true digestibility in the small intestine for amino 
TABLE 2

Amino acid composition (gAA/100gAA determined, $\mathrm{n}=16$ Cys and Trp excluded) of liquid associated bacteria isolated from the rumen of dairy cows

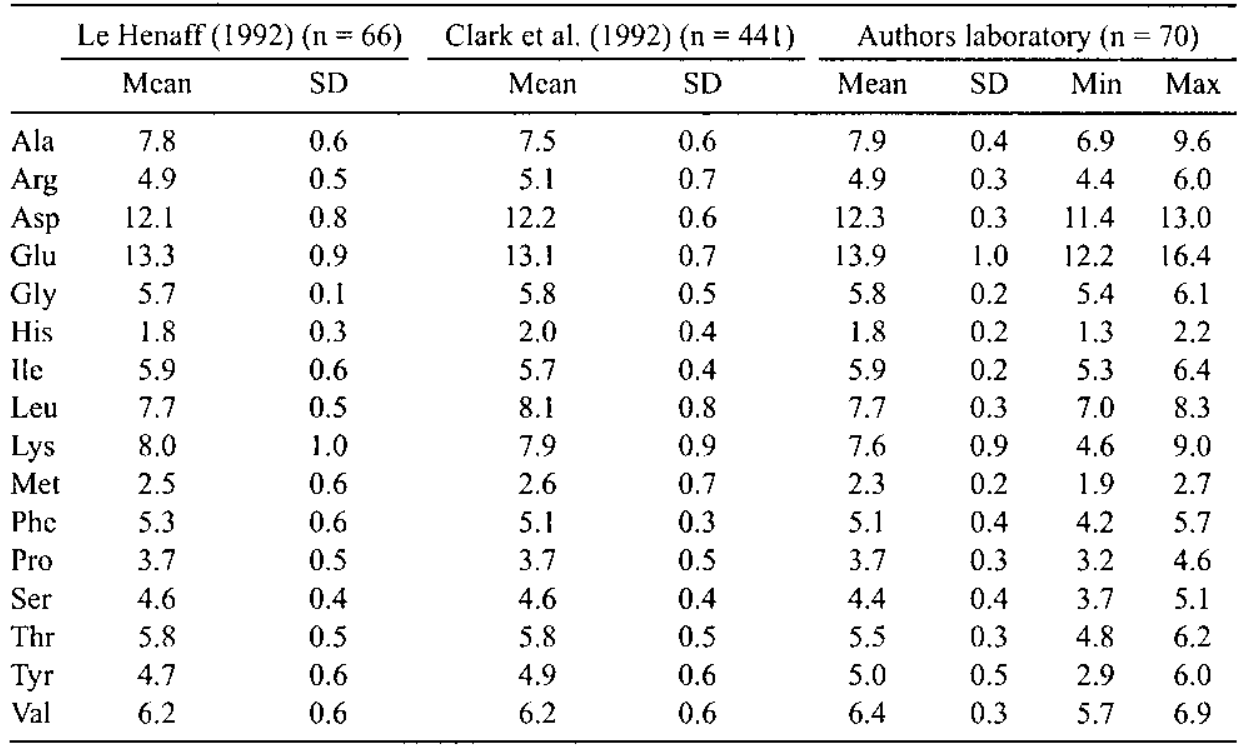

acid nitrogen in bacterial protein have been obtained by Tas et al. (1981), Storm et al. (1983) and Hvelplund (1985) by infusing bacterial protein into the abomasum. The values obtained varied between 0.85 and 0.87 . Estimates of amino acid digestibility in the small intestine of ruminants for protozoal protein are not available in the literaturc. However, protozoal protein has been fed to rats in a few experiments as summarized by Zinn and Owens (1982), and the true digestibility of crude protein in these experiments varied between 0.82 and 0.91 . This indicates that the estimate of digestibility for amino acids in mixed rumen bacteria may also apply to protozoa that contribute to the microbial protein entering the duodenum. Different new protein evaluation systems estimate the digestibility of microbial amino acids (bacteria + protozoa) in the small intestine as 0.80 to 0.85 . This narrow range reflects the relatively good agreement between the few available estimates of digestibility for this protein fraction.

Intestinal digestibility of individual amino acids in the small intestine of ruminants has been estimated by Storm et al. (1983) and Hvelplund and Hesselholt (1987). Except for cystine for which both studies agreed upon a value of approximately 0.75 , the individual amino acids had digestibilities close to the mean value of 0.85 observed for total amino acids. This mean value of 0.85 can therefore also be applied to individual amino acids in bacterial protein. 


\section{SUPPLY WITH AMINO ACIDS FROM UNDEGRADED DIETARY PROTEIN}

The microbial protein passing from the rumen to the small intestine is not sufficient to meet the requirement for intestinally absorbable amino acids in the high producing dairy cow. It is therefore necessary additionally to supply the dairy cow with amino acids from rumen undegraded protein. The variability found in the amino acid composition of duodenal chyme (Table 1) do indicate differences from one feeding situation to the other and although some of this variability can be related to variation in microbial composition, undegraded feed protein also contributes. To enable accurate prediction of the duodenal flow of individual amino acids, with the scope of supplying the dairy cow with an optimal blend of amino acids for milk production, it is necessary also to include the contribution of amino acids from undegraded dietary protein.

Table 3 shows the amino acid composition of milk, rumen bacteria and different feedstuffs normally included in diets for dairy cows. Based on the amino acid pro-

TABLE 3

Amino acid composition ( $\mathrm{g} \mathrm{AA} / 100 \mathrm{~g}$ AA determined, $\mathrm{n}=16 \mathrm{Cys}$ and Trp excluded) of bovine milk, rumen liquid associated bacteria $\mathrm{LAB}$, and selected roughages and concentrates

\begin{tabular}{lrrrrrrrrrrrrrrr}
\hline & Milk $^{1}$ & LAB $^{1}$ & GRA $^{1}$ & CGS $^{1}$ & \multicolumn{1}{c}{ GS $^{1}$} & MS $^{1}$ & Maize $^{2}$ & Wheat $^{2}$ & Barlcy $^{2}$ & SBM $^{2}$ & SFM $^{2}$ & RSM $^{2}$ & MDG $^{2}$ \\
\hline Obs $^{3}$ & 6 & 150 & 16 & 9 & \multicolumn{1}{c}{25} & \multicolumn{1}{l}{9} & 100 & 130 & 110 & 741 & 465 & 156 & 6 \\
Ala & 3.3 & 7.9 & 8.1 & 8.7 & 10.3 & 9.9 & 8.1 & 4.0 & 4.3 & 4.5 & 4.9 & 5.2 & 7.6 \\
Arg & 3.6 & 4.8 & 5.4 & 4.0 & 2.9 & 3.5 & 4.8 & 5.0 & 5.2 & 7.7 & 8.8 & 6.6 & 3.4 \\
Asp & 7.7 & 12.3 & 10.9 & 10.2 & 11.3 & 7.8 & 7.1 & 5.8 & 6.5 & 12.1 & 10.3 & 8.4 & 7.2 \\
Glu & 20.3 & 13.3 & 11.4 & 9.9 & 10.3 & 12.7 & 19.4 & 31.6 & 25.5 & 19.1 & 21.8 & 19.5 & 18.2 \\
Gly & 1.9 & 5.7 & 6.1 & 6.1 & 6.1 & 7.3 & 3.9 & 4.2 & 4.3 & 4.4 & 6.4 & 5.9 & 4.1 \\
His & 2.8 & 2.0 & 2.7 & 2.4 & 2.3 & 2.1 & 3.1 & 2.5 & 2.4 & 2.7 & 2.7 & 3.2 & 3.2 \\
Ile & 5.4 & 6.0 & 5.2 & 6.0 & 5.8 & 5.8 & 3.6 & 3.7 & 3.9 & 5.1 & 4.6 & 4.4 & 4.4 \\
Leu & 9.8 & 7.6 & 9.2 & 9.5 & 9.3 & 10.6 & 12.8 & 7.2 & 7.5 & 8.0 & 7.0 & 8.0 & 11.7 \\
Lys & 7.8 & 7.7 & 6.1 & 5.3 & 5.1 & 3.8 & 3.1 & 3.0 & 3.9 & 6.4 & 3.9 & 6.2 & 2.8 \\
Met & 2.5 & 2.2 & 2.0 & 2.1 & 2.0 & 2.1 & 2.2 & 1.7 & 1.8 & 1.5 & 2.5 & 2.3 & 2.3 \\
Phe & 4.6 & 5.1 & 6.1 & 5.7 & 5.8 & 5.6 & 5.0 & 4.8 & 5.4 & 5.2 & 5.0 & 4.5 & 4.9 \\
Pro & 9.4 & 3.6 & 5.8 & 8.9 & 8.7 & 7.1 & 9.3 & 10.5 & 11.7 & 5.3 & 4.8 & 6.8 & 10.1 \\
Ser & 5.6 & 4.6 & 5.2 & 5.3 & 4.9 & 6.1 & 5.0 & 5.1 & 4.7 & 5.4 & 4.8 & 5.0 & 5.6 \\
Thr & 4.2 & 5.6 & 5.3 & 5.1 & 4.9 & 5.1 & 3.7 & 3.1 & 3.7 & 4.0 & 4.1 & 5.0 & 4.6 \\
Tyr & 4.6 & 5.2 & $4.0^{3}$ & 3.3 & 2.7 & 3.1 & 3.9 & 2.9 & 3.4 & 3.7 & 2.8 & 3.4 & 3.9 \\
Val & 6.6 & 6.5 & 6.7 & 7.5 & 7.7 & 7.3 & 5.1 & 4.8 & 5.5 & 5.0 & 5.6 & 5.9 & 6.0 \\
\hline
\end{tabular}

1 compilation of Danish samples (Misciatte!li et al., unpublished)

${ }^{2}$ European amino acid table (Janssen et al., 1992)

${ }^{3}$ maximal number of observations, profile calculated based on data expressed in $\mathrm{g} \mathrm{AA} / 16 \mathrm{~g} \mathrm{~N}$

a mean value of published foreign values $(n=46)$

LAB: liquid associated bacteria, isolated from the rumen of dairy cows

GRA: fresh grass, all species. CGS: clover grass silage. GS: grass silage. MS: maize silage. SBM: soyabean meal SFM: sunflower meal

RSM: rapeseed meal. MDG: maize distillers grains 
files of the feedstuffs it is quite evident that the amino acid profiles for the essential amino acids deviates from the composition of milk. To be able to compose a diet where amino acids from the undegraded protein together with the microbial protein meets the requirement for milk production with respect to optimal amino acid composition it is necessary to know to what extend degradation of protein in the rumen may alter the amino acid composition of the feed protein.

\section{DEGRADATION IN THE RUMEN OF AMINO ACIDS IN FEED PROTEIN}

Crude protein digestibility is commonly used as an estimate for total amino acid degradability using the in situ method (Mehrez and Ørskov, 1977; Ørskov and McDonald, 1979) but the results of using crude protein as an estimate for total amino acids has not been conclusive (Hvelplund and Weisbjerg, 1998). The in situ method has also been used to investigate degradability of individual amino acids in a number of studies.

Considering that the different individual proteins differ in amino acid composition and degradation rate within a feed, it is not surprising that in situ investigations of individual amino acid degradation have revealed differences in the extent of ruminal degradation between individual amino acids in numerous studies (Crooker et al., 1986; Susmel et al., 1989; Antoniewicz et al., 1992; Boila and Ingalls, 1992; Skórko-Sajko et al., 1994; Dakowski et al., 1996; Skiba et al., 1996; Weisbjerg et al., 1996), but in other investigations notable differences have not been observed (Varvikko et al., 1983; Weakley et al., 1983; van Stralen et al., 1997; Piepenbrink and Schingoethe, 1998). Rates of deamination of free amino acids in the rumen have been investigated by Chalupa (1976), who found that lysine, phenylalanine, leucine and isoleucine were broken down at 0.2 to $0.3 \mathrm{mmol} \mathrm{h}^{-1}$, while arginine and threonine were more labile $\left(0.5-0.9 \mathrm{mmol} \mathrm{h}^{-1}\right)$, methionine and valine were more stabile and deaminated at rates between 0.1 to $0.14 \mathrm{mmol} \mathrm{h}^{-1}$. Chalupa (1976) concluded that free amino acids with the possible exception of methionine could not survive ruminal degradation. In agreement with this Kowalczyk (1994) concluded, after comparing in vitro and in vivo ruminal degradation of free amino acids, that amino acids disappeared faster in vivo than in vitro, and that only small proportions of free amino acids appeared at the duodenum. Other experiments has though indicated that a dose dependent ruminal escape of free amino acids takes place (Cottle and Velle, 1989; Sulu et al., 1989; Velle et al., 1997), and is enhanced by the dosage of free amino acids in mixtures (Velle et al., 1998) and that the apparent degradation rate of free amino acids is not dependent on feed level (Volden et al., 1998). There is thus substantial reason to believe that amino acid composition of undegraded feed protein flowing to the duodenum, is different compared to the original feed. Further a significant pro- 
portion of peptides and free amino acids in the rumen fluid escapes degradation and contributes to duodenal amino acid flow.

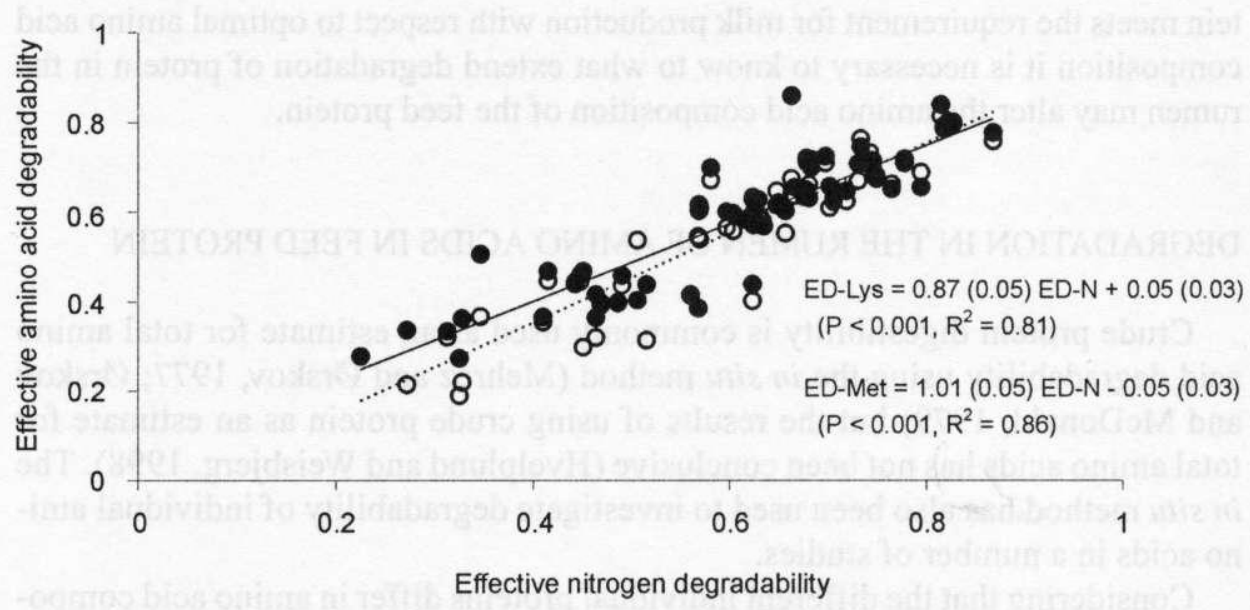

Figure 1. Correlation between effective nitrogen, Lys $(\bullet)$ and Met (o) degradability of different untreated concentrates $(\mathrm{n}=50)$ and $(\mathrm{n}=13)$ in the rumen determined by the in situ technique with corrections for particle loss according to Hvelplund and Weisbjerg (2000). Lines illustrate regressions between Lys (full line) and Met (dashed line) degradability and nitrogen degradability. Data from: Skiba et al. (1996), Weisbjerg et al. (1996), Lund et al. (unpublished) and Misciattelli et al. (unpublished)

Results from recent Danish studies including both roughage and concentrates show that the degradability obtained for nitrogen for some feeds are in agreement with the value obtained for individual amino acids (only lysine and methionine are shown) whereas for other feeds the value for nitrogen and individual amino acids is quite different as shown in Figure 1. The implication of this is that at least for some feeds a correct estimate of the contribution with individual amino acids at the intestinal level requires estimates of rumen degradability of individual amino acids.

\section{INTESTINAL DIGESTIBILITY OF AMINO ACIDS IN RUMEN UNDEGRADED FEED PROTEIN}

Estimates of the true digestibility of protein and amino acids in the small intestine from experiments in which undegraded protein was infused in the intestine of ruminants are scarce. Applying regression techniques, Tas et al. (1981) reported a value of 0.82 for the true digestibility of undegraded amino acids passing to the duodenum of sheep fed a diet of grass and concentrates. Hvelplund (1985) measu- 
red the increments in protein and amino acids passing the terminal ileum when different proteins, which had previously been exposed to some degradation in the rumen, were infused into the abomasum of sheep. This experiment showed that the protein and amino acids in different undegraded proteins were digested to a variable degree in the small intestine. Thus, protein and amino acid digestibility of undegraded feed protein varies especially if the protein sources are treated to protect the protein against degradation. The protection apparently influences digestibility negatively as shown by Kaufmann and Lüpping (1982) and Hvelplund (1985). Because of variable digestibility of undegraded feed protein, there is a need to assess the digestibility of undegraded dietary protein for all types of feeds. However, in vivo experiments and use of infusion techniques for estimation of post ruminal digestion of undegraded dietary protein can only be applied to a limited extent as they are costly and time consuming. Therefore, alternative methods have been evaluated.

The mobile nylon bag technique has made it possible to evaluate the digestibility of undegraded protein for a variety of feeds. This technique can be used to determine differences between feeds for disappearance of protein in the small intestine (Hvelplund, 1985; Voigt et al., 1985; DeBoer et al., 1987) but it assumes a high correlation between disappearance and true digestibility in vivo. Good agreement between disappearance from the bags and true intestinal digestibility in vivo has been obtained by Todorov and Girginov (1991) and Hvelplund et al. (1994), indicating that the mobile nylon bag method can be used to predict small intestinal digestibility, as illustrated in Figure 2, where the true intestinal digestibility of

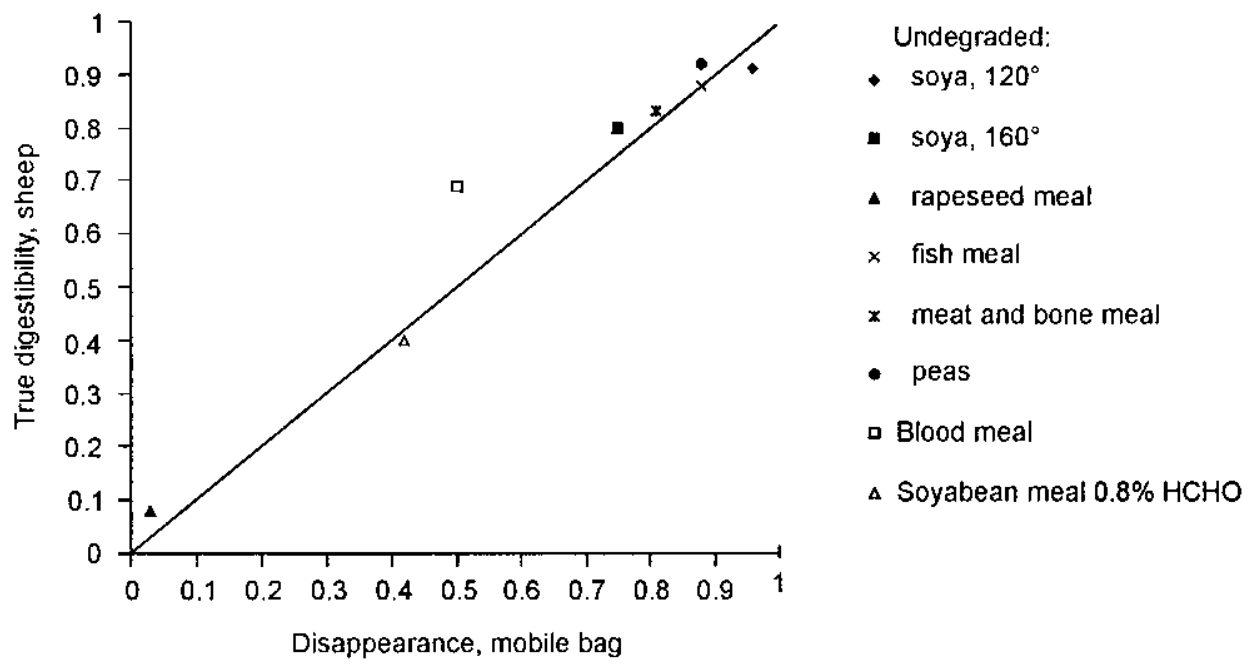

Figure 2. The relation between the disappearance of protein from the nylon bags and the true digestibility of protein in the small intestine of sheep. - $x=y$ (Hvelplund et al., 1994) 
protein was estimated with sheep on intragastric infusion and related to the disappearance of protein from the mobile nylon bag. In contrast to this Vanhatalo and Varvikko (1995) found a 30\% units higher disappearance from the mobile bag, compared to in vivo digestibility in the intestine using ${ }^{15} \mathrm{~N}$ labelled rapeseed.

Intestinal digestibility of undegraded dietary protein can be predicted from total digestibility of original feed protein and information on the actual rumen degradability according to the following equation (Hvelplund et al., 1992).

$$
\mathrm{TD}=(\mathrm{UDN}-\mathrm{TU}) / \mathrm{UDN}
$$

where TD $=$ true digestibility of rumen undegraded protein in the small intestine,

UDN = fraction of undegraded dietary protein, and

$\mathrm{TU}=$ fraction of true indigestible protein in the feed.

This equation is valid for a variety of different concentrates and roughages where total digestibility has been estimated as the disappearance from mobile bags passing the intestine, and is currently used in the Danish version of the AAT-PBV protein evaluation system. The feed composition tables list the total tract true digestibility of the original feed protein together with the protein degradability, thus making it possible to calculate intestinal digestibility of undegraded feed protein, by the equation above.

The assumption that total digestibility can be estimated as small intestinal disappearance from the mobile bags can be questioned. Mgheni et al. (1994) showed that for tropical roughages the potential degradability in the rumen was substantially higher than the digestibility of original protein in the small intestine measured with the mobile bag technique. This is probably due to the content of tannins and to a high proportion of cell wall bound nitrogen in tropical roughages which cannot be solubilized by intestinal enzymes, but may be digested in the rumen due to the combined action of proteolytic and cellulolytic microbial enzymes. This may also be true for temperate roughages at a late stage of maturity. Similar problems may occur with other feeds such as grains in which protein is protected by starch which limits the access of intestinal enzymes (Volden and Harstad, 1995). Therefore, the procedure used in Denmark includes a $16 \mathrm{~h}$ preincubation of the mobile bags in the rumen.

The value obtained using the mobile nylon bag method represents the true digestibility in the small intestine, even though microbial contamination of feed residues during passage through the terminal ileum and hindgut is a potential risk. The magnitude of contamination has been examined with ${ }^{15} \mathrm{~N}$ marked roughages (Jarosz et al., 1994). It was shown, that disappearance of nitrogen was higher for bags recovered from faeces compared to those recovered from the terminal ileum in most cases. The disappearance of nitrogen compared to true nitrogen disappearance $\left({ }^{15} \mathrm{~N}\right)$ was lower at both places of recovery. This experiment also showed that 
the nitrogen disappearance from the bags recovered in the faeces was a good estimate of the true $\left({ }^{15} \mathrm{~N}\right)$ disappearance from the small intestine as measured with bags recovered from the ileum. Also the results of Voigt et al. (1985) indicates a good correlation between estimates of intestinal digestibility, determined from mobile bags collected either at the ileum or from faeces, while Boila and Ingalls (1992) concluded that mobile bags recovered in faeces were less sensible to identify differences in digestibility between individual amino acids.

The mobile bag is normally used to measure total protein digestibility, but can also be used to estimate digestibility of amino acids (Hvelplund et al., 2001) which is the value required in the modern protein evaluation systems. In a study by Weisbjerg et al. (1996), which included 15 different concentrates, it was shown that total amino acid digestibilities were similar to protein digestibilities. Results from recent Danish studies including both roughage and concentrates show that the intestinal digestibility obtained for nitrogen for some feeds are in agreement with the value obtained for individual amino acids (only lysine and methionine are shown) whereas for other feeds the value for nitrogen and individual amino acids is quite different as shown in Figure 3. The implication of this is that at least for some feeds it is necessary to estimate the intestinal digestibility of individual amino acids as the intestinal digestibility of nitrogen do not apply for individual amino acids.

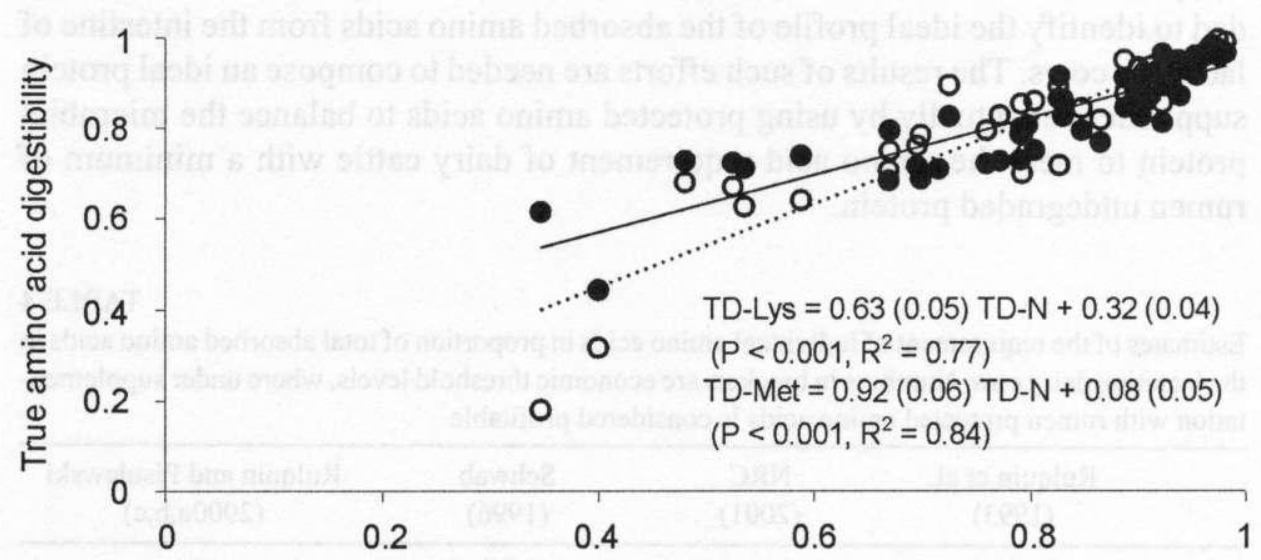

True nitrogen digestibility

Figure 3. Correlation between true intestinal nitrogen, Lys $(\bullet)$ and Met (o) digestibility of different untreated concentrates $(n=41)$ and roughages $(n=13)$ determined by the mobile bag technique after preincubation in the rumen. Lines illustrate regressions between Lys (full line) and Met (dashed line) digestibility and nitrogen digestibility. Data from: Skiba et al.(1996), Weisbjerg et al. (1996), Lund et al. (unpublished) and Misciattelli et al. (unpublished) 


\section{REQUIREMENT FOR INDIVIDUAL AMINO ACIDS FOR MILK PRODUC- TION}

The amino acid requirements of dairy cattle are not known with much certainty. Attempts have been made to quantify amino acid requirement of cattle using the factorial approach (Buttery and Foulds, 1985; O'Connor et al., 1993; Oldham, 1994). An alternative and more direct approach in defining amino acid requirement is to use the dose-response approach to estimate the amino acid requirement. Thus far, most progress has been made for lysine and methionine and these amino acids have often been identified as the first limiting amino acids under a variety of different conditions (Rulquin et al., 1993). The role of histidine as a potentially limiting amino acid has also been demonstrated (Kim et al., 1999; Vanhatalo et al., 1999), as has the beneficial effect of post ruminal infusion of proline (Bruckental et al., 1991). Improved N-balance has been observed in response to post ruminal infusion of leucine in lactating cows (Iburg and Lebzien, 2000), while Robinson et al. (1999) observed a tendency towards increased milk yield when infusing isoleucine post ruminally. A range of possibly limiting amino acids has thus been identified under different conditions involving post ruminal infusion of AA. Table 4 shows estimates of the requirement of individual amino acids in proportion of total absorbed amino acids in lactating dairy cows. The table show that there is good agreement with respect to requirement for lysine and methionine from different authors. However, more research is needed to identify the ideal profile of the absorbed amino acids from the intestine of lactating cows. The results of such efforts are needed to compose an ideal protein supplement eventually by using protected amino acids to balance the microbial protein to meet the amino acid requirement of dairy cattle with a minimum of rumen undegraded protein.

TABLE 4 Estimates of the requirement of individual amino acids in proportion of total absorbed amino acids in the lactating dairy cow. Numbers in brackets are economic threshold levels, where under supplementation with rumen protected amino acids is considered profitable

\begin{tabular}{lcccc}
\hline & $\begin{array}{c}\text { Rulquin et al. } \\
(1993)\end{array}$ & $\begin{array}{c}\text { NRC } \\
(2001)\end{array}$ & $\begin{array}{c}\text { Schwab } \\
(1996)\end{array}$ & $\begin{array}{c}\text { Rulquin and Pisulewski } \\
(2000 \mathrm{a}, \mathrm{b}, \mathrm{c})\end{array}$ \\
\hline Lys & $7.3 \%(6.8 \%)$ & $7.3 \%$ & $7.0-8.0 \%$ & \\
Met & $2.5 \%(2.0 \%)$ & $2.4 \%$ & $2.5-2.7 \%$ & \\
Leu & & & & $8.9-11.1 \%$ \\
His & & & & $3.4-5.6 \%$ \\
Phe & & & & $4.6-5.8 \%$ \\
\hline
\end{tabular}




\section{CONCLUSIONS}

The results seem to indicate that degradability and digestibility estimates obtained for nitrogen may not always apply to individual amino acids and more research is needed to identify the ideal profile of the amino acids absorbed from the intestine of lactating cows. Results of such efforts are needed to compose an ideal protein supplement eventually by using protected amino acids to balance the microbial protein to meet the amino acid requirement of dairy cattle with a minimum of rumen undegraded protein.

\section{REFERENCES}

AFRC, 1992. Nutritive requirements of ruminant animals: protein. AFRC Technical Committee on Responses to Nutrients: Report No. 9. Nutr. Abstr. Rev., Ser. B 62, 787-835

Antoniewicz A.M., van Vuuren A.M., van der Koelen C.J., Kosmala I., 1992. Intestinal digestibility of rumen undegraded protein of formaldehyde-treated feedstuffs measured by mobile bag and in vitro technique. Anim. Feed Sci. Tech. 39, 111-124

Bergen W.G., Purser D.B., Cline J.H., 1968. Effect of ration on the nutritive quality of rumen microbial protein. J. Anim. Sci. 27, 1497-1501

Boila R.J., Ingalls J.R., 1992. In situ digestion and escape of dry matter, nitrogen and amino acids in canola meal. Can. J. Anim. Sci. 72, 891-901

Boila R.J., Ingalls J.R., 1994. The post ruminal digestion of dry matter, nitrogen and amino acids in wheat-based distillers dried grains and canola meal. Anim. Fecd Sci. Tech. 49, 173-188

Bruckental I., Ascarelli I., Yosif B., Alumot E., 1991. Effect of duodenal proline infusion on milk production and composition in dairy cows. Anim. Prod. 53, 299-303

Buttery P.J., Foulds A.N., 1985. Amino acid requirements of ruminants. ln: W. Haresign, D.J.A. Cole (Editors). Recent Advances in Animal Nutrition. Nottingham University Press, Nottingham, pp. 257-271

Chalupa W., 1976. Degradation of amino acids by the mixed rumen microbial population. J. Anim. Sci. $43,828-834$

Clark J.H., Klusmeyer T.H., Cameron M.R., 1992. Microbial protein synthesis and flows of nitrogen fractions to the duodenum of dairy cows. J. Dairy Sci. 75, 2304-2323

Cottle D.J., Velle W., 1989. Degradation and outflow of amino acids from the rumen of sheep. Brit. J. Nutr. 61, 397-408

Crooker, B.A., Clark, J.H., Shanks, R.D., Hatfield E.E., 1986. Effects of ruminal exposure on the amino acid profile of heated and formaldehyde-treated soybean meal. J. Dairy Sci. 69, 26482657

Dakowski P., Weisbjerg M.R., Hvelplund T., 1996. The effect of temperature during processing of rape seed meal on amino acid degradation in the rumen and digestion in the intestine. Anim. Feed Sci. Tech. 58, 213-226

de Boer G, Murphy J.J., Kennelly J.J., 1987. Mobile nylon bag for estimating intestinal availability of rumen undegradable protein. J. Dairy Sci. 70, 977-982

Hvelplund T., 1985. Digestibility of rumen microbial protein and undegraded dietary protein estimated in the small intestine of sheep or by sacco procedure. Acta Agr. Scand., Suppl. 25, $132-144$ 
Hvelplund T., Madsen J., 1985. Amino acid passage to the small intestine in dairy cows compared with estimate of microbial protein and undegraded dietary protein from analysis on the feed. Acta. Agr. Scand., Suppl. 25, 21-36

Hvelplund T., Hessetholt M., 1987. Digestibility of individual amino acids in rumen microbial protein and undegraded dictary protein in the small intestine of sheep. Acta Agr. Scand. 37, 459-477

Hvelplund T., Hovell F.D.DeB., Ørskov E.R., Kyle D.J., 1994. True intestinal digcstibility of protein estimated with sheep on intragastric infusion and with the mobile nylon bag technique. Proc. Soc. Nutr. Physiol. 3, 64

Hvelplund T., Misciattelli L., Hovell F.D.DeB., Weisbjerg M.R., 2001. True intestinal digestibility of nitrogen, lysine and methionine estimated with sheep on intragastric infusion and by mobile bag technique. Abstract, IAAFSC Joint Meeting, Indiana, July 2001 (accepted)

Hvelplund T., Weisbjerg M.R., 1995. Begrænsende aminosyrer i mælkeproduktionen. Proceding fra fagscminar; Proteinvurdering - drøvtyggere. Norges Landbohøjskole, As, pp. $42-52$

Hvelplund T., Weisbjerg M.R., 1998. In vitro techniques to replace in vivo methods for estimating amino acid supply. In: E.R. Deaville, E. Owen, A.T. Adesogan, C. Rymer, J.A. Huntington, T.L.J. Lawrence (Editors). In Vitro Techniques for Measuring Nutrient Supply to Ruminants. Occasional Publication No. 22. Brit. Soc. Anim. Sci. pp. 131-144

Hvelplund T., Weisbjerg M.R., 2000. In situ techniques for the estimation of protein degradability and postrumen availability. In: D.I. Givens, E. Owen, R.F.E. Axford, H.M. Omed (Editors). Forage Evaluation in Ruminant Nutrition. CABI Publishing, Wallingford, pp. 233-258

Hvelplund T., Weisbjerg M.R., Andersen. L.S., 1992. Estimation of the true digestibility of rumen undegraded protein in the small intestine of ruminants by the mobile bag technique. Acta Agr. Scand., Sect. A., Anim. Sci. 42, 34-39

lburg M., Lebzien P., 2000. Requirements of lactating dairy cows for leucine and methionine at the duodenum. Livest. Prod. Sci. 62, 155-168

Janssen W.M.M.A., Ingelaat F.B.J.M., Schaper Sj., McNab J., 1992. European Amino Acid Table. COVP-DLO, Beekbergen (The Netherlands), pp. 123

Jarosz L., Hvelplund T., Wcisbjerg M.R., Jensen B.B., 1994. True digestibility of protein in the small intestine and the hind gut of cows measured with the mobile bag technique using $15 \mathrm{~N}$-labelled roughage. Acta. Agr. Scand., Sect. A, Anim. Sci. 44, 146-151

Kaufmann W., Lüpping W., 1982. Protected proteins and amino acids for ruminants. In: E.L. Miller, I.H. Pike, A.J.H. Van Es. (Editors). Protein Contribution of Feedstuffs for Ruminants: Application to Feed Formulation. Butterworth Scientific, London, pp. 36-75

Kim C.H., Choung J.J., Chamberlain D.G.,1999. Determination of the first-limiting amino acid for milk production in dairy cows consuming a diet of grass silage and a cereal-based supplement containing feather meal. J. Sci. Food. Agr. 79, 1703-1708

Kowalczyk J., 1994. The rate of free amino acid disappearance from the rumen content. J. Anim. Feed Sci. 3, 11-22

Le Henaff L., 1992. Importance des acides amines dans la nutrtion des vaches laitières. These de Docteur de l'Universite de Rennes I, No. 253. INRA - Station de Recherches sur la Vache Laitière, St-Gilles (France), pp. 126

Mehrez A.Z., Orskov E.R., 1977. A study of the artificial fibre bag technique for determining the digestibility of feeds in the rumen. J. Agr. Sci. 88, 645-650

Mgheni D.M., Hvelplund T., Weisbjerg M.R., 1994. Intestinal digestibility of rumen undegraded dietary protein from tropical roughages estimated by the mobile bag method. Acta Agr. Scand., Sect. A., Anim. Sci. 44, 230-235 
NRC, 2001. Protein and Amino Acids. In: Nutrient Requirements of Dairy Cattle. 7 th revised Edition. National Rescarch Council, Subcommittee on Dairy Cattle Nutrition. Washington, DC, pp. 43-104

O'Connor J.D., Sniffen C.J., Fox D.G., Chalupa W., 1993. A net carbohydrate and protein system for evaluating cattle diets: IV. Predicting amino acid adequacy. J. Anim. Sci. 71, 1298-1311

Oldham J.D., 1994. Amino acid nutrition of the dairy cow. In: J.P.F D'Mello (Editor). Amino Acids in Farm Animal Nutrition. CABI, Wallingford, pp. 351-375

Ørskov E.R., McDonald I., 1979. The estimation of protein degradability in the rumen from incubation measurements weighted according to rate of passage. J. Agr. Sci, 92, 499-503

Piepenbrink M.S., Schingocthe D.J., 1998. Ruminal degradation, amino acid composition, and estimated intestinal digestibilities of four protein supplements. J. Dairy Sci. 81, 454-461

Purser D.B., Buechler S.M., 1966. Amino acid composition of rumen organisms. J. Dairy Sci. 49, $81-84$

Robinson P.H., Chalupa W., Sniffen C.J., Julien W.E., Sato H., Fujieda T., Watanabe K., Suzuki H., 1999. Influence of post ruminal supplementation of methionine and lysine, isoleucine, or all three amino acids on intake and chewing behavior, ruminal fermentation, and milk and milk component production. J. Anim. Sci. 77, 2781-2792

Rulquin H., Pisulewski P.M, 2000a. Effects of duodenal infusion of graded amounts of His on mammary uptake and metabolism in dairy cows. J. Anim. Sci. 83, Suppl. 1, 164 (Abstr.)

Rulquin H., Pisulewski P.M, 2000b. Effects of duodenal infusion of graded amounts of Leu on mammary uptake and metabolism in dairy cows. J. Anim. Sci. 83, Suppl. 1, 164 (Abstr.)

Rulquin H., Pisulewski P.M, 2000c. Effect of duodenal infusion of graded amounts of Phe on mammary uptake and metabolism in dairy cows. J. Anim. Sci. 83, Suppl. 1, 267-268 (Abstr.)

Rulquin H., Pisulewski P.M, Vérité R., Guinard J., 1993. Milk production and composition as a function of post ruminal lysine and methionine supply: a nutrient-response approach. Livest. Prod. Sci. 37, 69-90

Schwab C.G., 1996. Rumen-protected amino acids for dairy cattle: progress towards determining lysine and methionine requirements. Anim. Feed Sci. Tech. 59, 87-101

Skiba B., Weisbjerg M.R., Hvelplund T., 1996. Rumen and total intestinal tract digestibility of protein and amino acids from different roughages determined in situ. J. Anim. Feed Sci. 5, 347-363

Skórko-Sajko H., Hvelplund T., Weisbjerg M.R., 1994. Rumen degradation and intestinal digestibility of amino acids in different roughages estimated by nylon bag techniques. J. Anim. Feed Sci. 3, $1-10$

Storm E., Brown D.S., Ørskov E.R., 1983. The nutritive value of rumen microorganism in ruminants. 3 . The digestion of microbial amino and nucleic acids in, and losses of endogenous nitrogen from the small intestine of sheep. Brit. J. Nutr. 50, 479-485

Sulu N., Bjørnstad K., Grønseth D., Velle W., 1989. Ruminal degradation and outflow of amino acids in cows. J. Vet. Med. 36, 55-63

Susmel P., Stefanon B., Mills C.R., Candido M., 1989. Change in amino acid composition of different protein sources after rumen incubation. Anim. Prod. 49, 375-383

Tas M.V., Evans R.A., Axford R.F.E., 1981. The digestibility of amino acids in the small intestine of the sheep. Brit. J. Nutr. 45, 167-174

Todorov N.A., Girginov D.G., 1991. Comparison of the infusion method, mobile bag technique and in vitro method for determination of the true protein digestibility in small intestine of cattle. In: B.O. Eggum, S. Boisen, C. Børsting, A. Danfær, T. Hvelplund (Editors). Protein Metabolism and Nutrition. Proceedings of the $6^{\text {th }}$ International Symposium on Protein Metabolism and Nutrition. Vol. 2. National Institute of Animal Science (Denmark), pp. 80-82 
Van Straalen W.M., Odinga M.J.J., Mostert W., 1997. Digestion of feed amino acids in the rumen and small intestine of dairy cows measured with nylon-bag techniques. Brit. J. Nutr. 77, 83-97

Vanhatalo A., Varvikko T., 1995. Effect of rumen degradation on intestinal digestion of nitrogen of $15 \mathrm{~N}$-labeled rapeseed meal and straw measured by the mobile-bag method in cows. J. Agr. Sci. 125, 253-261

Vanhatalo A., Huhtanen P., Toivonen V., Varvikko T., 1999. Response of dairy cows fed grass silage diets to abomasal infusions of histidine alone or in combination with methionine and lysine. J. Dairy Sci. 82, 2674-2685

Varvikko T., Lindberg J.E., Setälä J., Syrjälä-Qvist L., 1983. The effect of formaldehyde treatment of soya-bean meal and rapeseed meal on the amino acid profiles and acid-pepsin solubility of rumen undegraded protein. J. Agr. Sci. 101, 603-612

Velle W., Kanui T.I., Aulie A., Sjaasatd Ø.V., 1998. Ruminal escape and apparent degradation of amino acids administered intraruminally in mixtures to cows. J. Dairy Sci. 81, 3231-3238

Velle W., Sjaastad Ø.V., Aulic A., Grønset D., Feigenwinter K., Framstad T., 1997. Rumen cscape and apparent degradation of amino acids after intraruminal administration to cows. J. Dairy Sci. $80,3325-3332$

Voigt J., Piatkowski B., Engelmann H., Rudolph E., 1985. Measurement of the postruminal digestibility of crude protein by the bag technique in cows. Arch. Tierernähr. 35, 555-562

Volden H., Harsted O.M., 1995. Effect of rumen incubation on the true indigestibility of feed protein in the digestive tract determined by nylon bag techniques. Acta. Agr. Scand., Sect. A, Anim. Sci. $45,106-115$

Volden H., Velle W., Harstad O.M., Aulie A., Sjaastad Ø.V., 1998. Apparent ruminal degradation and rumen escape of lysine, methionine, and threonine administered intraruminally in mixtures to high-yiclding cows. J. Anim. Sci. 76, 1232-1240

Weakley D.C., Stern M.D., Satter L.D., 1983. Factors affecting disappearance of feedstuffs from bags suspended in the rumen. J. Anim. Sci. 56, 493-507

Weisbjerg M.R., Hvelplund T., Hellberg S., Olsson S., Sanne S., 1996. Effective rumen degradability and intestinal digestibility of individual amino acids in different concentrates determined in situ. Anim. Feed Sci. Tech. 62, 179-188

Zinn R., Owens F.N., 1982. Predicting net uptake of non-ammonia N from the small intestine. In: F.N. Owens (Editor). Protein Requirements of Cattle. Oklahoma State University, Stillwater, OK, pp. 133-140 


\section{STRESZCZENIE}

\section{Zabezpieczenie krów mlecznych w aminokwasy pochodzące $z$ bialka paszy}

Ilość białka produkowanego przez drobnoustroje w żwaczu nie pokrywa zapotrzebowania na aminokwasy przez wysokoprodukcyjne krowy mleczne. Nicdobory te moga być pokryte dodatkiem odpowiedniej ilości białka paszy, które nie ulega degradacji w żwaczu. Białko takie powinno uzupelniać zapotrzebowanie tak pod względem ilościowym jak i jakościowym, co stwarza warunki do jego efektywnego wykorzystania do produkcji mleka.

W tej pracy przedstawiono wyniki badań dotyczące skladu aminokwasowego i strawności aminokwasów pochodzenia mikrobiologicznego. Główny akcent położono jednak na ostatnie badania nad rozkładalnością i strawnością poszczególnych aminokwasów białka pasz. Uzyskane wyniki wskazują, że wartości otrzymane dla rozkładalności i strawności azotu nie zawsze można odnieść do poszczególnych aminokwasów. W celu wyjaśnienia tego zagadnienia potrzebne są dalsze badania dla ustalenia idealnego profilu aminokwasów wchłanianych z jelita u krów mlecznych. Dane takie sa potrzebne dla opracowania idealnego dodatku białkowego, ewentualnie przy użyciu aminokwasów chronionych, celem zbilansowania białka pochodzenia mikrobiologicznego, dla pokrycia zapotrzebowania na aminokwasy przez bydło mleczne, $z$ minimalnym udziałem białka nierozkładalnego w żwaczu. 